published) even the rhizome apex seems to have a discrete hypodermis and the aerial shoot often approximates to the state of affairs in Fig. $k$. The condition represented in Fig. $l$ can be found at the tip of the developing inflorescence of Agropyron, but this may not be a permanent feature. The possibility of three tiers of internal initials is also suggested for some of the main shoots in bamboos (Phyllostachys ${ }^{3}$ and Sinocalamus ${ }^{4}$ ), but there is need for further investigation here.

Axillary buds have a construction either similar to or simpler than the main apex. Thus in Avena, Secale and Triticum, where periclinal divisions are frequent in the hypodermis at the tip of the main shoot, a similar situation is found in the apices of the axillary buds. On the other hand, in Agropyron, Sinocalamus ${ }^{4}$ and $Z e a$, where the hypodermis remains as a discrete layer at the tip of the main shoot, periclinal divisions are absent from the apices of the axillary buds.

For want of a better term, the cells to which the internal layers can be traced back in the apex have been termed 'initials', but it is only rarely that they approach anything at all like the classical idea of an apical initial. They are not large, well-defined, wellvacuolated cells cutting off segments with a volume considerably smaller than their own. Instead they are usually rich in cytoplasm and divide into almost (? quite) equal parts, and the one which happens to be nearer the tip is destined to continue as the initial merely because of its position. All the cells of quite a large group are totipotent, and their positioning in the apex is probably governed by laws comparable with those which determine the packing patterns of bubbles in the end of a test tube rather than by any qualities inherent in the cells themselves. Moreover, the position taken up by a cell governs its subsequent development.

The view that the exact mode of origin of the inner tissues of the apex is not significant is further confirmed by the constant development behind the apex of the hypodermis and sub-hypodermis, often quite irrespective of details of segmentation at the actual tip, demonstrated especially by apices of the type shown in Fig. $d$. From recent studies it is becoming increasingly evident that the zonation of all apices is to be thought of in terms of levels of relative differences in aeration, nutrition, etc. It is not a morphological but a metabolic zonation rather akin to a gardener's 'top-soil' and 'sub-soil'. The nearer a cell is to the surface, the more it tends to divide exclusively by anticlinal walls, an effect which bears absolutely no relationship to the number or positioning of the 'initial' cells, and which leads to the production a little way back from the extreme tip of clearly distinguishable layers, the numbers of which will tend to be greater the more massive the apex. In grass apices of the long type this zonation will be very noticeable; but it will be masked in short apices by the divisions connected with the onset of leaf and bud initiation. The metabolic view also makes the observed occasional periclinal divisions unconnected with leaf initiation in the dermatogen itself to be expected, especially in very young axillary buds or the plumules of young seedlings.

Since the exact origin and fate of the various layers are so flexible in the grass apex, Hanstein's terminology cannot be used in its strict sense, nor is the tunica-corpus terminology in Buder's ${ }^{5}$ (but not in Schmidt's ${ }^{6}$ and Foster's ${ }^{7}$ ) sense very useful. However, using these and Koch's ${ }^{8}$ similar terminology (originally suggested for Gymnosperms) purely as descriptive of the tissue zonation of the apex without any implications as to derivation or destiny, the equivalents are as follows:

\begin{tabular}{|c|c|c|c|}
\hline Tissue & Hanstein & Koch & Tunica-corpus \\
\hline Outer layer & Dermatogen & $\begin{array}{l}\text { Mantle } \\
\text { (Hullgewebe) }\end{array}$ & Tunica \\
\hline $\begin{array}{l}\text { Hypodermis } \\
\text { Sub-hypo- } \\
\text { dermis }\end{array}$ & $\begin{array}{l}\text { Outer periblem } \\
\text { Inner periblem }\end{array}$ & $\begin{array}{l}\text { Mantle } \\
\text { Mantle }\end{array}$ & $\begin{array}{l}\text { Tunica } \\
\text { Corpus (? or } \\
\text { transition }\end{array}$ \\
\hline Inner core cells & Plerome & Central tissue & $\begin{array}{l}\text { layer) } \\
\text { Corpus }\end{array}$ \\
\hline
\end{tabular}

The construction of the apex has considerable interest for the plant-breeder who wishes to obtain viable gametes by doubling the chromosome complement with colchicine, etc. This is obviously best achieved by affecting the tissues eventually traceable to the hypodermis of the flower-bud primordia. $\mathrm{He}$ need not consider whether the main axis has a single initial or a group of initials for both the hypodermis and the inner tissues, and whether or not periclinal divisions occur in the apical cells of the hypodermis of axillary buds. He must merely realize that the earlier he treats his seedling the better because: (1) in young seedlings the whole of the hypodermis is being derived from fewer initials, so that should he have the good fortune to produce a doubling in an initial, it will produce a wide sector of cells with the new constitution, and it may also be the parent of some of the other initials when the group increases in number ; (2) even if he succeeds in only doubling the complement of a hypodermal cell on the flank of the apex, if effected early this will be represented in all the tiller buds from that sector, whereas successively later local doubling in the hypodermis will only affect blocks of primary, secondary and then tertiary, etc., inflorescence buds (in the case of a paniculate inflorescence), or spikelet buds and later only floret initials.

${ }^{1}$ Kliem, F., Beit. Biol. Pflanzen, 24, 281 (1937).

${ }^{2}$ Rösler, P., Beit. Biol. Pflanzen, 5, 28 (1928).

s Porterfleld, W. M., Peking Soc. Nat. Hist. Bull., 4 (3), 7 (1930).

'Hsü, J., Amer. J. Bot., 31, 404 (1944).

${ }^{5}$ Buder, J., Ber. Bot. Ges., 46, 20 (1928).

${ }^{6}$ Schmidt, A., Bot. Arch., 8, 345 (1924).

'Foster, A. S., Bot. Rev., 5, 454 (1939).

Koch, L., Jahrb. wiss. Bot., 22, 491 (1891).

\section{EXPERIMENTAL MORPHOLOGY OF PTERIDOPHYTES}

$\mathrm{P}$

HYSIOLOGICAL and experimental observations have hitherto played virtually no part in helping to elucidate problems connected with the organization of the plant body in Pteridophytes. The approach towards these problems has been almost exclusively morphological in inception and outlook. Some experimental investigations recently recorded by Prof. C. W. Wardlaw (Ann. Bot., New Series, 7, Nos. 26 and 28, 8, Nos. 30/31 and 32, April and Oct. 1943 and April-July and Oct. 1944) dealing with bud development and stelar morphology in ferns have yielded results of great interest and significance which indicate the value and potentialities of this previously neglected approach to morphological problems.

It has long been held that one of the morphologicál characteristics distinguishing ferns from seed 
plants is the inconstancy in the positional relationship of buds to shoot and leaf in the former group. Though sometimes they occupy definite axillary positions, they commonly arise in extra-axillary positions which apparently show no fixed relationship to the foliar organs. Prof. Wardlaw's observations, however, suggest that, though the final position of the bud is so variable, its point of initiation does in fact show a definite relation to the foliar organs, and the ultimate position it comes to occupy is explicable in terms of relative growth activities.

Investigations on Matteuccia struthiopteris and Onoclea sensibilis have shown that, on the normally unbranched rhizomes of these dictyostelic species, buds may be induced by removal of the terminal meristem. These buds are initiated in superficial areas of meristematic cells which, in the normal rhizome, remain quiescent. The origin of the patches of meristematic cells can be traced to the apical meristem, from which they become detached and persist on the surface of the shoot in definite positions corresponding to the point of union of the meristeles at the distal end of the leaf gap, that is, in the axis of a leaf but some distance above its insertion.

In Dryopteris Filix-mas, defoliation experiments involving the removal of fronds and destruction by puncturing with a needle of the smallest visible leaf primordia proved effective in bud formation. The buds were situated either on the leaf-base near its point of confluence with the shoot or some distance along the petiole. Investigation showed that the buds always arise on the shoot in an approximately axillary position, despite the abaxial position at some distance above the petiole base which they eventually may come to occupy. Their origin was traced to the activity of epidermal cells lying in close proximity to points of meristele conjunction in the vascular meshwork of the shoot and therefore comparable in position with those of the other species investigated.

The position which the bud ultimately comes to occupy on the petiole is due to the very great transverse growth expansion of the basal region of a developing leaf primordium. This causes displacement of the much more slowly growing bud from its original axillary position, and leads to its being carried up on the enlarging base of a developing frond. The enlarging frond base on which the bud is thus caught up may lie in a longitudinal or a lateral position with respect to the bud, so that the bud may become separated in space from the leaf to which it originally stood in an axillary relationship.

Further observations along these lines may well reveal that the point of origin of buds is fundamentally the same in all ferns, and that the varied positions which they eventually occupy may be wholly explicable in terms of specific growth distribution in shoot and leaf.

In the field of stelar morphology, chief consideration has always been devoted to fully differentiated tissue systems ; and though a fairly complete picture has been obtained of the progressive increase in complexity of the stele during ontogeny, little attention has been paid to the development of the shoot as a whole from the apex backwards. Hence developmental studies in the stelar morphology of ferns, comparable in detail with the ontogenetic studies of their reproductive structures or with the dynamic aspect of tissue differentiation behind the growing point in the Angiosperms, are not available.
Prof. Wardlaw recognizes two phases in the development of vascular tissues, namely, the "initial differentiation", whereby vascular tissue can be distinguished from cortical tissue, and the "subsequent differentiation" characterized by the specialized development of the constituent vascular elements. It is in the region situated immediately below the apical meristem that the "initial differentiation" takes place, and it is suggested as a working hypothesis that this initial differentiation of vascular tissue is inseparably connected with the immediate proximity of an apical meristem in a state of active growth, its position and behaviour being causally related to one or more unspecified substances diffusing from the meristematic cells.

Evidence adduced for the Pteridophytes in general is fully in accord with the fact that wherever an actively growing apex is present, vascular tissue may be observed in the process of differentiation immediately behind it. Moreover, that the maintenance of the actively meristematic condition is all-important is indicated by the disappearance of the zone of initial differentiation behind dormant apices. It is shown that the discontinuous vascular strands which have been described by Holloway in large prothalli of Psilotum triquetrum are associated with discontinuous apical activity, while instances cited of vascular tissue differentiation in experimentally induced buds on fern rhizomes, in the protocorms of Lycopods and their attached leaves, and in certain regenerative growth processes which have been described in Lycopodium Selago, all clearly point to the fact that where the apical growth is not actively maintained, stelar tissue is not differentiated.

The application of experimental methods to the problem of the relation of leaf development to stelar morphology in ferns has yielded results of outstanding interest. These results throw new light on the factors determining the form of the axial stele and supply an answer to the much-debated question of the cauline versus foliar nature of the stem stele.

It was observed that in Dryopteris Filix-mas, immediately below the apical meristem, there is an uninterrupted ring of vascular tissue in the initial stage of differentiation, while in the earliest stages of development of the fronds the vascular supply to the young primordia shows no leaf gaps. These develop a little later, their formation being associated with mechanical stresses resulting from the enlargement of the vascular systems of the leaf bases. Experimental verification of this relationship was sought by defoliating rhizomes and destroying the young leaf primordia by needle puncturing with a micro-manipulator. The apical meristematic cone alone was left intact. The rhizomes were planted in moist peat and new leaf primordia were regularly destroyed as they developed. The suppression of leaf growth was found to lead to the failure of leaf gaps to form, and therefore to the substitution of a solenostele in place of the dictyostele characteristic of this species. When new leaf primordia were allowed to develop again on treated rhizomes, the specimens showed solenostely in the treated region. of the shoot, with a return to normal dictyostely in the terminal region. Similar experimentally induced solenosteles were obtained in Onoclea sensibilis. The development of a substantial shoot stele in both species in the absence of any associated leaf growth affords proof of the truly cauline nature of the stele.

W. A. Sledge. 